\title{
A survey of the Endangered Barbary macaque Macaca sylvanus in the Central High Atlas Mountains of Morocco
}

\author{
A b Derrazak El Alami, Els van Lavieren, Rachida Aboufatima \\ and ABDERRAHMAN CHAIT
}

\begin{abstract}
The Barbary macaque Macaca sylvanus is the only macaque in Africa. The species is categorized as Endangered on the IUCN Red List and is listed in CITES Appendix II. This macaque has a relict distribution in Morocco and Algeria. Recent studies have indicated a dramatic decline of Barbary macaque populations in the Middle Atlas and Rif Mountains in Morocco but there is limited available information on its distribution in the Central High Atlas. We therefore conducted interviews with local officials and inhabitants, and carried out field surveys in 12 sites from February 2004 to December 2008. We found Barbary macaques in relatively small and fragmented habitats in 10 of the 12 sites. A total of 35 groups were sighted and 644 individuals counted. Mean group size was 21 (range 6-42). In all surveyed sites habitat destruction and pressure from livestock were apparent. The interviews indicated that the macaques are often found in the proximity of agricultural land, and that there is evidence of illegal capture in the Bas Oued El Abid and Haut Oued El Abid areas. To protect this species we recommend establishment of protected areas specifically for the Barbary macaque, increased surveillance by forest guards, enforcement of the law against capture of the species, and education of the local people.
\end{abstract}

Keywords Barbary macaque, geographical distribution, High Atlas, Macaca sylvanus, Morocco

\section{Introduction}

The Barbary macaque Macaca sylvanus is categorized as Endangered on the IUCN Red List (Butynski et al., 2008) and is listed in CITES Appendix II (CITES Trade Database Report, 2011). It is the only macaque species that occurs beyond Asia (Fooden, 1982), and its current

AbDERRAZAK El Alami (Corresponding author) and ABDERrahman Chait Laboratory of Pharmacology, Neurobiology and Behaviour, Faculty of Sciences Semlalia, University of Caddy Ayyad Rue de Prince Moulay Abdellah, B.P. 2390, 40000 Marrakech, Morocco. E-mail departementbiologiefssm@hotmail.com

Els van Lavieren Moroccan Primate Conservation Foundation, Amsterdam, The Netherlands

RaCHIDA Aboufatima Laboratory of Bioengineering, Faculty of Sciences and Technology, University of Sultan Moulay Slimane, Beni Mellal, Morocco

Received 2 June 2011. Revision requested 21 July 2011.

Accepted 19 August 2011. distribution is limited to relict habitats in Morocco and Algeria (Taub, 1977; Fa et al., 1984; Camperio Ciani, 1986; Scheffrahn et al., 1993). A semi-wild population occurs in Gibraltar (Joleaud, 1931; Modolo et al., 2005; Perez \& Bensusan, 2005). In the early 1980s the global population of Barbary macaques was estimated to be $14,000-23,000$ ( $\mathrm{Fa}$ et al., 1984). In the 1990s the population was 10,000-16,000 (Lilly \& Mehlman, 1993; Von Segesser et al., 1999). The total Moroccan population is now estimated to be 5,000-6,000 (Waters et al., 2007; van Lavieren \& Wich, 2009), a large decline since 2003, when the Moroccan population was estimated to be c. 10,000 (Camperio Ciani \& Palentini, 2003). No recent data has been published on the status of the Algerian population. Between 65 and $75 \%$ of the surviving population occurs in the cedar Cedrus atlantica forests of the Middle Atlas (Taub, 1977; Camperio Ciani, 1986). In this area the density of macaques was estimated to be 44-70 $\mathrm{km}^{-2}$ in the late 1970s (Deag, 1977; Taub, 1977; Fa et al., 1984) but recent studies indicate a dramatic decline (Camperio Ciani et al., 2005; Van Lavieren \& Wich, 2009). In the Rif the population in the Djebela region decreased from 200 to 89 between 1980 and 2004 (Waters et al., 2007).

The main factors responsible for the decline of this species in Morocco are habitat destruction, the impact of livestock grazing, and illegal capture (Van Lavieren, 2004, 2008; Camperio Ciani et al., 2005; Waters et al., 2007; Van Lavieren \& Wich, 2009). Limited information is available on the Barbary macaque distribution in the High Atlas. A few scattered groups occur in disturbed habitats in the Occidental High Atlas, and small fragmented populations were previously known to occur in the Central and Oriental High Atlas (Fa et al., 1984; Cuzin, 1996, 2003). The objective of this study was to determine the current status of the Barbary macaque populations in the Central High Atlas of Morocco, to describe any human-macaque conflicts and to make recommendations for the protection of the Barbary macaque in this area.

\section{Study area}

The study was conducted in the Central High Atlas of Morocco (Fig. 1). The terrain, mainly calcareous, consists of steep mountain slopes and rocky gorges dissected by swiftly running streams. Altitudes are $600-2,600 \mathrm{~m}$. The region's climate varies from semi-arid to sub-humid (Emberger, 


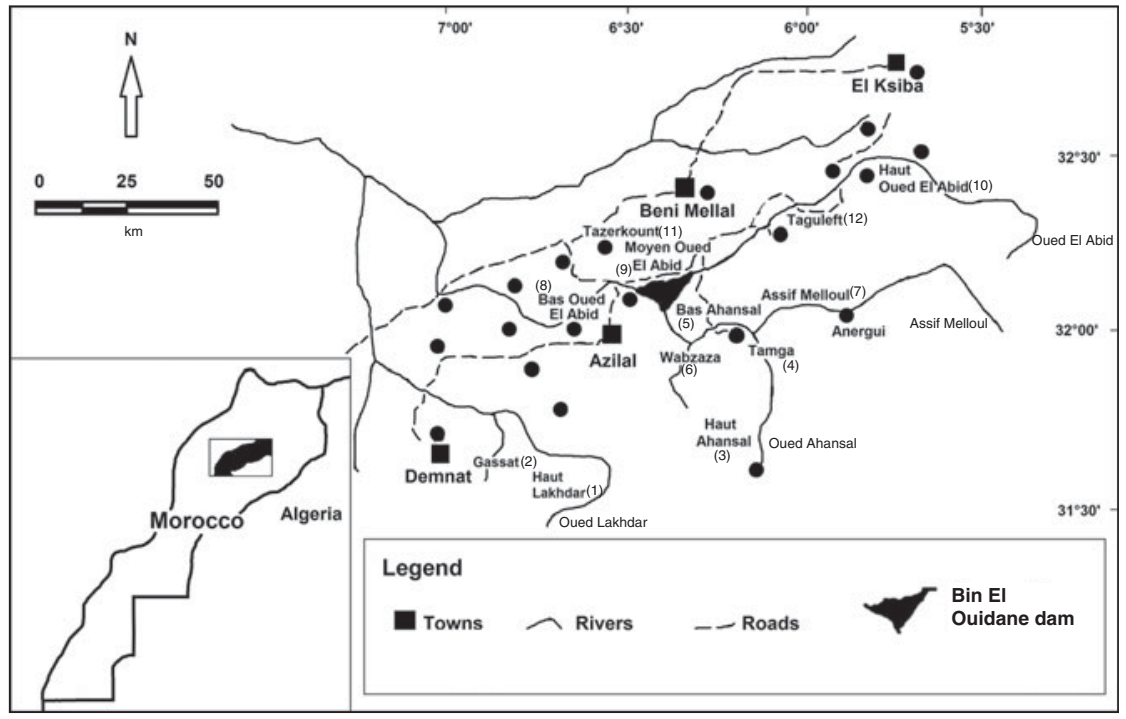

FIg. 1 The study area in the Central High Atlas, showing the locations of the sites (1-12; Table 1) where we surveyed for the Barbary macaque Macaca sylvanus, the four main valleys (Oued Lakhdar, Oued Ahansal, Assif Melloul and Oued El Abid), and the villages (black dots) in which the interviews were conducted. The rectangle on the inset indicates the location of the main map in Morocco.

TABLE 1 Locations, survey date, survey effort, total $\mathrm{km}$ surveyed, habitat type(s), number of groups sighted, mean group size and individuals counted of the Barbary macaque Macaca sylvanus in the central High Atlas of Morocco (Fig. 1) in 2004-2008. Protected sites are denoted by an asterisk.

\begin{tabular}{|c|c|c|c|c|c|c|c|c|}
\hline $\begin{array}{l}\text { Location (site in } \\
\text { Fig. 1), by valley }\end{array}$ & Survey date & $\begin{array}{l}\text { No. of } \\
\text { surveys }\end{array}$ & $\begin{array}{l}\text { Survey } \\
\text { effort } \\
\text { (days) }\end{array}$ & $\begin{array}{l}\text { Total } \\
\mathrm{km} \\
\text { surveyed }\end{array}$ & Habitat type & $\begin{array}{l}\text { No. of } \\
\text { groups } \\
\text { sighted }\end{array}$ & $\begin{array}{l}\text { Mean group } \\
\text { size (range) }\end{array}$ & $\begin{array}{l}\text { No. of } \\
\text { individuals }\end{array}$ \\
\hline Oued Lakhdar & & & & & & & $12(6-28)$ & 94 \\
\hline Haut Lakhdar (1) & $\begin{array}{l}\text { Aug. 2006; Mar.- } \\
\text { Apr. } 2008\end{array}$ & 3 & 9 & 41 & $\begin{array}{l}\text { Open forest \& } \\
\text { non-wooded land }\end{array}$ & 5 & & \\
\hline Gassat-Tifni (2) & Mar.-Apr. 2008 & 1 & 5 & 27 & $\begin{array}{l}\text { Open forest \& } \\
\text { non-wooded land }\end{array}$ & 3 & & \\
\hline Oued Ahansal & & & & & & & $19(7-37)$ & 185 \\
\hline $\begin{array}{l}\text { Haut Oued } \\
\text { Ahansal (3) }\end{array}$ & June 2007 & 1 & 4 & 18 & Open forest & 2 & & \\
\hline Tamga* $^{*}(4)$ & Jan. 2006; Aug. 2007 & 2 & 7 & 35 & Pine oak forest & 3 & & \\
\hline $\begin{array}{l}\text { Bas Oued } \\
\text { Ahansal (5) }\end{array}$ & Mar. 2006; Dec. 2007 & 4 & 14 & 43 & Open forest & 2 & & \\
\hline Wabzaza* $^{*}(6)$ & May 2005; Oct. 2007 & 3 & 21 & 38 & Mixed forest & 3 & & \\
\hline Assif Melloul & & & & & & & $16(7-26)$ & 63 \\
\hline Assif Melloul (7) & $\begin{array}{l}\text { May-June 2006; Mar. } \\
2008\end{array}$ & 3 & 17 & 31 & $\begin{array}{l}\text { Thermophilous scrub } \\
\text { (gorges \& cliffs) }\end{array}$ & 4 & & \\
\hline Oued El Abid & & & & & & & $23(9-42)$ & 302 \\
\hline $\begin{array}{l}\text { Bas Oued } \\
\text { El Abid (8) }\end{array}$ & $\begin{array}{l}\text { Feb. 2004; Apr.-May } \\
\text { 2006; Apr. } 2008\end{array}$ & 6 & 13 & 18 & $\begin{array}{l}\text { Thermophilous scrub } \\
\text { (gorges \& cliffs) }\end{array}$ & 4 & & \\
\hline $\begin{array}{l}\text { Moyen Oued } \\
\text { El Abid (9) }\end{array}$ & $\begin{array}{l}\text { Sep. 2006; Feb.-Mar. } \\
2007\end{array}$ & 5 & 18 & 38 & Open oak forest & 2 & & \\
\hline $\begin{array}{l}\text { Haut Oued } \\
\text { El Abid (10) }\end{array}$ & $\begin{array}{l}\text { Nov. 2006; Mar.- } \\
\text { May 2007; Jan.- } \\
\text { Mar. } 2008\end{array}$ & 7 & 34 & 64 & Mixed forest & 7 & & \\
\hline Tazerkount* (11) & Jan.-Feb. 2008 & 1 & 4 & 17 & Oak forest & 0 & & \\
\hline Taguleft (12) & Jan. 2008 & 1 & 5 & 14 & Open forest & 0 & & \\
\hline Total & 2004-2008 & 37 & 151 & 384 & & 35 & $21(7-42)$ & 644 \\
\hline
\end{tabular}

1934, 1939; Sauvage, 1963). A description of the 12 surveyed sites is given in Table 1. The study area consists of nonwooded terrain, agricultural land, fragmented forests and brushwood. The main forms of land use are shifting agriculture and pastoralism. The habitat types in Sites 1, 2, 3,
5, 6, 8 and 9 are principally pure holm oak Quercus ilex or mixed with juniper (Juniperus phoenicea, Juniperus oxycedrus and Juniperus thurifera) and Barbary thuya Tetraclinis articulata. The forest located east of the town of Beni Mellal (Site 10) contains oak mixed with sparse cedars Cedrus 
atlantica. Open forests of Aleppo pine Pinus halepensis occur in the valleys of Oued Ahansal and Assif Melloul (Sites 4 and 7 ).

\section{Methods}

In the Middle Atlas line transect surveys have been successfully used to estimate the densities of macaques (Camperio Ciani et al., 1996, 1999, 2005; Van Lavieren \& Wich, 2009), and this is the most common method of censusing primate populations (e.g. Cant, 1978; Green, 1978; Glenn, 1998; Gonzalez-Kirchner, 1998; Wallace et al., 1998). However, the topography of the Rif and High Atlas Mountains is not conducive to such systematic surveys (Fa et al., 1984; Cuzin, 1996, 2003; Waters et al., 2007).

Therefore, we could not use distance sampling methods (Buckland et al., 2001, 2010) to estimate the density of macaques. We used a combination of standardized interviews combined with a direct count survey to gather information about the presence or absence of macaques in specific areas and to determine the relative abundance of the macaque in each site. Surveys took place between February 2004 and December 2008. These sites were previously known to have had macaque populations ( $\mathrm{Fa}$ et al., 1984; Cuzin, 1996, 2003). The direct survey method entails counting individual animals or groups of animals. With the help of shepherds, who know the location of macaque groups in the areas where they graze their herds, macaque groups were identified and individuals counted.

Interviews were conducted from February 2004 to December 2008 with 15 officials of the Moroccan forestry department and a total of 119 inhabitants of 21 villages and of the towns of Beni Mellal, Azilal, Demnat, El Ksiba (Fig. 1), and in Ouaouezarht south of Bin El Ouidane dam. The questionnaire was administered in the local language (Tamazight) which is the first language of $\mathrm{AE}, \mathrm{RA}$ and AC; in some villages the authors were known, motivating people to speak freely. We focused on shepherds and firewood collectors because of their knowledge of the environment in which they work. The local names of the Barbary macaque are zaatout and lkard in the Oued El Abid and the Oued Ahansal areas, abagouss and lkard in the Oued Lakhdar area, and idoun and lkard in the Assif Melloul area. Colour pictures of a chimpanzee and a Barbary macaque were shown and five questions were asked: (1) Did the interviewees recognize the Barbary macaque? (2) Are macaques present in the region? (3) Are macaques present year-round or seasonally? (4) Do macaques raid crops and cause damage? (5) Are macaques captured and/or killed in the region?

To search for and count macaques a team of 2-7 observers spent a total of 151 days surveying macaques in the 12 sites where the species had been reported. The number of kilometres surveyed and time spent surveying in a region is summarized in Table 1. Before visiting sites we questioned people in nearby villages about their knowledge of Barbary macaques and existing paths. In particular we interviewed residents older than 40 years, shepherds and firewood collectors. Based on the information gathered we conducted surveys on foot. Observers (the authors and 2-5 local inhabitants) walked on pre-existing trails normally used by shepherds and other local people. The observers moved slowly and quietly along the path at a rate of $0.5-1.5 \mathrm{~km} \mathrm{~h}^{-1}$, stopping periodically to watch and listen for macaques. Surveys took place from dawn to dusk. All the paths were mapped and their lengths calculated. Sightings of macaques, habitat quality, and presence of livestock were recorded during the survey. In these mountainous habitats the macaque groups were often spread over a large area and only a few individuals were visible. Except for the group at the tourist site of Ouzoud in the Bas Oued El Abid site (Site 8), the groups were not habituated to humans. The most common response of macaques to the approach of humans is to flee. This can be accompanied by vocalizations. Macaques are most often detected when moving, feeding or vocalizing. When a macaque group was observed the observers followed the group and chose the best place to obtain a count of individuals. For each group the individuals were counted either when they were in non-wooded land or when they crossed rivers or paths, using binoculars if necessary. Repetition of surveys, in combination with the location of the group sightings enabled us to differentiate individual groups.

\section{Results}

Seventy-one percent of the interviewed inhabitants recognized the picture of the Barbary macaque, and eight forestry officials and 52 inhabitants confirmed the presence of macaques at Sites 1-10 but not at Sites 11 (Tazerkount) and 12 (Taguleft). At Tazerkount four inhabitants indicated they had observed macaques in 1997 and showed two pictures of macaques on the road between Beni Mellal and Azilal. Information collected in the interviews also indicated that the capture of macaques occurs in Bas Oued El Abid (Site 8) and Haut Oued El Abid (Site 10). In all sites where macaques are present the interviewees mentioned that macaques come close to agricultural land and occasionally cause damage to crops.

The results of the surveys confirmed the information from the interviews and showed that the distribution of the Barbary macaque in the Central High Atlas is now restricted to 10 small areas in the main valleys (Oued El Abid, Oued Ahansal, Oued Lakhdar and Assif Melloul). We sighted a total of 35 groups and counted a total of 644 individual macaques. Mean group size was 21 with a range of 6-42 individuals (Table 1). The surveys confirmed that macaques do not occur in Tazerkount or Taguleft, or in the forest 
downstream of the lake of Bin El Ouidane (part of Site 9), and in the mountains to the south of the town of Beni Mellal (also part of Site 9). Barbary macaques were observed in a wide range of habitats but $49 \%$ of the groups were seen in oak forests. Macaques were also found in areas containing junipers, Aleppo pine and Barbary thuya. One group lives in the tourist site of Ouzoud (part of Site 8) where macaques are habituated to humans and partly provisioned by food offered to them. We noted that in all places where we located macaques their habitat is subject to destruction and pressures from livestock. We frequently encountered firewood collectors or observed their permanent camps, and flocks of sheep and goats were always present in all surveyed sites. Only the most inaccessible forests of the reserves of Wabzaza (Site 6), Tazerkount (Site 11), Tamga (Site 4) and Bou Tferda (part of Site 10) were found to be still relatively intact and undisturbed.

\section{Discussion}

Ideally, our survey would have been carried out using distance sampling (Buckland et al., 2001, 2010). However, the survey sites were in many cases steep cliffs and other mountainous topography where it was not possible to delineate and walk transects. Furthermore, this topography makes it hard to detect macaques whilst they are fleeing and thus distances to groups or individuals are difficult to estimate. The fact that we surveyed at irregular intervals during 2004-2008 rather than within a more restricted period could have resulted in an overestimate of the macaque population in the Central High Atlas. However, the survey method that we used can provide information about changes in population status and patterns of human impact, and is thus sufficient for examining trends and defining management responses.

Our results concur with those of Fa et al. (1984) and Cuzin $(1996,2003)$ in indicating that in the Central High Atlas the Barbary macaque occurs in relatively small and fragmented areas restricted to the main valleys at altitudes of $700-2,400 \mathrm{~m}$. Compared to these earlier studies, however, we found that the species no longer occurs in four localities. This could be attributed to habitat degradation, hunting activities, the impact of livestock grazing, and disturbance by people. As deforestation for agriculture and overgrazing continues, the remaining forest becomes increasingly fragmented. Consequently, the Barbary macaque is now restricted to small, fragmented relict habitats (Cuzin, 2003; this study).

Our study confirms earlier findings (Taub, 1977; Fa et al., 1984; Cuzin, 2003) that the Barbary macaque can occupy a wide range of habitats. We observed macaques in open and closed forests of oak, juniper, Aleppo pine, and Barbary thuya, in rocky mountain ridges, and at a tourist site. The
Barbary macaque is recognized for its adaptability, and is generally considered an eclectic feeder (Deag, 1974; Drucker, 1984; Mehlman, 1984; Ménard, 1985; Ménard \& Vallet, 1986). Our surveys and Cuzin (2003) indicate that in the Central High Atlas this macaque appears to have a preference for oak and pine forests and is confined to inaccessible rocky slopes and gorges. The highest numbers of macaques were mostly found in protected sites; outside these the macaques were found in small numbers. Generally, the sizes of the groups sighted were small and group size was highly variable. The Barbary macaque can be used as a biological indicator of forest quality (Mouna et al., 1999; Camperio Ciani et al., 1999, 2001; Camperio Ciani \& Palentini, 2003), and the demographic differences between the populations living in different habitats are the results of deforestation, overgrazing and human interferences (Mehlman, 1989).

The conservation of Barbary macaque requires assessing the quality of remaining habitats and evaluating the impacts of human influences. Increasing human activity has enhanced the opportunities for contact between people and the macaques. Consequently, the damage caused to crops by macaques is escalating and macaques have become victims of trapping for the pet trade. We recommend four measures to reduce the likelihood of this Endangered species of macaque becoming extinct in the Central High Atlas of Morocco: (1) establishment of protected areas specifically for the species in locations where it is extant, (2) increased surveillance by forest guards, (3) enforcement of the existing law against illegal capturing of macaques, and (4) education to raise the awareness of the local people about the Barbary macaque. These measures are detailed in the National Conservation Action Plan for the Barbary macaque in Morocco, which was finalized in November 2012.

\section{Acknowledgements}

This research was conducted with the authorization of the University of Caddy Ayyad, Marrakech, Morocco, and the Moroccan Forestry Department (Haut Commissariat aux Eaux et Forêts et à la Lutte Contre la Désertification). We thank the local officials of the Moroccan Forestry Department, the local population and the mountain guides of Azilal and Beni Mellal provinces, and the members of association SOS-MAGOTS, France.

\section{References}

Buckland, S.D., Anderson, D.R., Burnham, K.P., LaAke, J.L., Borchers, D.L. \& Thomas, L. (2001) Introduction to Distance Sampling: Estimating Abundance of Biological Populations. Oxford University Press, Oxford, UK.

Buckland, S., Plumtre, A., Thomas, L. \& Rexstad, E. (2010) Design and analysis of line transects for primates. International Journal of Primatology, 31, 833-847. 
Butynski, T.M., Cortes, J., Waters, S., Fa, J., Hobbelink, M.E., VAn LaVieren, E. et al. (2008) Macaca sylvanus. In IUCN Red List of Threatened Species v. 2012.2. Http://www.iucnredlist.org [accessed 12 February 2013].

Camperio Ciani, A. (1986) La Macaca sylvanus in Marocco: sopravvivenza o estinzione. Osservazioni personali e datistorico-demografici. Antropologia Contemporanea, 9, 117-132.

Camperio Ciani, A., Arahou, M. \& Mouna, M. (1996) Macaca sylvanus as a biological indicator to monitor the cedar forest of Morocco. Folia Primatologica, 67, 63-80.

Camperio Ciani, A., Martinoli, L., Capiluppi, C., Arahou, M. \& Mouna, M. (2001) Effects of water availability and habitat quality on bark stripping behaviour in Barbary macaques. Conservation Biology, 15, 259-265.

Camperio Ciani, A., Mouna, M. \& Arahou, M. (1999) Macaca sylvanus as a biological indicator of the cedar forest quality. In Selected Proceedings of the First International Conference on Biodiversity and Natural Resources Preservation, pp. 91-98. Al Akawayn University Press, Ifrane, Morocco.

Camperio Ciani, A. \& Palentini, L. (2003) La deserticazione in Marocco: uso degli indicatori biologici nel monitoraggio della deserticazione delle foreste del Medio Atlante. Antropologia Mediterranea, 1, 57-68.

Camperio Ciani, A., Palentini, L., Arahou, M., Martinoli, L., Capiluppi, C. \& Mouna, M. (2005) Population decline of Macaca sylvanus in the Middle Atlas of Morocco. Biological Conservation, $121,635-641$.

Cant, J.G.H. (1978) Population survey of the spider monkey Ateles geoffroyi at Tikal, Guatemala. Primates, 19, 525-535.

CITES (2011) Trade Database Report. Http://www.unep-wcmc.org/ citestrade/ [accessed 29 April 2011].

Cuzin, F. (1996) Répartition actuelle et statut des grands Mammifères sauvages du Maroc (Primates, Carnivores, Artiodactyles). Mammalia, 60, 101-124.

Cuzin, F. (2003) Les grands mammifères du Maroc méridional (Haut Atlas, Anti Atlas et Sahara): Distribution, écologie et conservation. MSc thesis. University of Montpellier II, Montpellier, France.

DEAG, J.M. (1974) A study of the social behaviour and ecology of the wild Barbary macaque Macaca sylvanus. L. PhD thesis. University of Bristol, Bristol, UK.

DEAG, J.M. (1977) The status of the Barbary macaque Macaca sylvanus in captivity and factors influencing its distribution in the wild. In Studies in Primate Conservation (eds H.S.H. Rainier \& G.H. Bourne), pp. 267-287. Academic Press, New York, USA.

DruCKer, G.R. (1984) The feeding ecology of the Barbary macaque and cedar forest conservation in the Moroccan Moyen Atlas. In The Barbary Macaque: A Case Study in Conservation (ed. J.E. Fa), pp. 135-164. Plenum Press, New York, USA.

Emberger, L. (1934) Tableau phytogéographique du Maroc. Première partie. Mémoires de la Société des Sciences naturelles du Maroc, no. $38,187 \mathrm{pp}$.

Emberger, L. (1939) Aperçu général sur la végétation du Maroc. Commentaire de la carte phytogéographique du Maroc. 1:5,000,000. Veröffentlichungen des geobotanischen Institutes Rübel in Zurich, $14,40-157$.

Fa, J.E., Taub, D.M., Ménard, N. \& Stewart, P.J. (1984) The distribution and current status of the Barbary Macaque in North Africa. In The Barbary Macaque: A Case Study in Conservation (ed. J.E. Fa), pp. 79-111. Plenum Press, New York, USA.

FoOdEN, J. (1982) Ecogeographic segregation of macaque species. Primates, 23, 574-579.
Glenn, M.E. (1998) Population density of Cercopithecus mona on the Caribbean Island of Grenada. Folia Primatologica, 69, 167-171.

Gonzalez-Kirchner, J.P. (1998) Group size and population density of the black howler monkey (Alouatta pigra) in Muchukux Forest, Quintana Roo, Mexico. Folia Primatologica, 69, 260-265.

Green, K.M. (1978) Primate censusing in northern Colombia: a comparison of two techniques. Primates, 19, 537-550.

Joleaud, L. (1931) Le rôle des singes dans les traditions populaires Nord-Africaines. Journal de la Société des Africaniste, 1, 117-150.

Lilly, A.A. \& Mehlman, P.T. (1993) Conservation update on the Barbary macaque. I. Declining distribution and population size in Morocco. American Journal of Primatology, 30, 327.

Mehlman, P.T. (1984) Aspect of the ecology and conservation of the Barbary macaque in the fir forest habitat of the Moroccan Rif mountains. In The Barbary macaque: A Case Study in Conservation (ed. J.E. Fa), pp. 165-199. Plenum Press, New York, USA.

Mehlman, P.T. (1989) Comparative density, demography, and ranging behavior of Barbary macaques (Macaca sylvanus) in marginal and prime conifer habitats. International Journal of Primatology, 10, 269-292.

Ménard, N. (1985) Le régime alimentaire de Macaca sylvanus dans différents habitats d'Algérie: I-régime en chênaie décidue. Revue d'Ecologie (la Terre et la Vie), 40, 451-466.

Ménard, N. \& Vallet, D. (1986) Le régime alimentaire de Macaca sylvanus dans différents habitats d'Algérie: II—régime en forêt sempervirentes et sur les sommets rocheux. Revue d'Ecologie (la Terre et la Vie), 41, 173-192.

Modolo, L., Salzburger, W. \& Martin, R.D. (2005) Phylogeography of Barbary macaques (Macaca sylvanus) and the origin of the Gibraltar colony. Proceedings of the National Academy of Sciences of the United States of America, 102, 7392-7397.

Mouna, M., Arahou, M. \& Camperio Ciani, A. (1999) A propos des populations du singe magot (Macaca sylvanus) dans le Moyen Atlas. Selected Proceedings of the First International Conference on Biodiversity and Natural Resources Preservation, pp. 105-109. Al Akawayn University Press, Ifrane, Morocco.

Perez, C.E. \& Bensusan, K.J. (2005) Upper Rock Nature Reserve: A Management Action Plan. Gibraltar Ornithological \& Natural History Society, Gibraltar, Spain.

Sauvage, C. (1963) Etages bioclimatiques. Comité de Géographie du Maroc, Atlas du Maroc, Notices explicatives, no. 6b. Rabat, Morocco.

Scheffrahn, W., Menard, N., Vallet, D. \& Gaci, B. (1993) Ecology, demography, and population genetics of Barbary macaques in Algeria. Primates, 34, 381-394.

TAUB, D.M. (1977) Geographic distribution and habitat diversity of the Barbary macaque Macaca sylvanus L. Folia Primatologica, 27, 108-133.

Van Lavieren, E. (2004) The illegal trade in the Moroccan Barbary macaque (Macaca sylvanus) and the impact on the wild population. MSc thesis. Oxford Brookes University, Oxford, UK.

VAn Lavieren, E. (2008) The illegal trade in Barbary macaques from Morocco and its impact on the wild population. TRAFFIC Bulletin, 21, 123-130.

Van Lavieren, E. \& Wich, Serge, A. (2009) Decline of the Endangered Barbary macaque Macaca sylvanus in the cedar forest of the Middle Atlas Mountains, Morocco. Oryx, 44, 133-138.

Von Segesser, F., Ménard, N., Gaci, B. \& Martin, D. (1999) Genetic differentiation within and between isolated Algerian 
subpopulations of Barbary macaques (Macaca sylvanus): evidence from microsatellites. Molecular Ecology, 8, 433-442.

Wallace, R.B., Painter, R.L.E. \& Taber, A.B. (1998)

Primate diversity, habitat preferences, and population

density estimates in Noel Kempff Mercado National Park, Santa

Cruz Department, Bolivia. American Journal of Primatology, 46, 197-211.

Waters, S.S., Aksissou, M., El Harrad, A., Hobbelink, M.E. \& FA, J.E. (2007) Holding on the Djebela: Barbary macaque Macaca sylvanus in northern Morocco. Oryx, 41, 106-108.

\section{Biographical sketches}

Abderrazak El Alami has spent 10 years carrying out research on the Barbary macaque and conservation in the High Atlas. Els vaN Lavieren is founder of the Moroccan Primate Conservation foundation and has been working on the conservation of the Barbary macaque in Morocco since 2004. AbDerrahman Chait and Rachida Aвоufatima are researchers on ecology and physiology of animals, with a particular interest in the conservation of the Barbary macaque. 